\title{
LATEST DEVELOPMENTS ON EQUIPMENT TO IMPROVE SAFETY AND WORKING CONDITIONS ON WIRE-ROD MILLS*
}

Andrea Zanon ${ }^{1}$

Nilson Alves Ferreira Junior ${ }^{2}$

\begin{abstract}
Recently steel manufacturers have significantly focused their attention on safety and working conditions thanks to new labour laws, comprehensive operators' knowledge and increased company social responsibility. Even with a reduced budget, investments on safety are now widely approved. Mill constructors aim at developing upgraded solutions to comply with these new requirements. In some cases mill constructors can even anticipate customers' requests and consequently put into the market innovative solutions. In this text we will analyze some advanced solutions developed by Danieli \& C. Officine Meccaniche Spa - the leading company in longproduct rolling mills - aimed at improving working conditions on wire-rod block settings. In particular, we will focus on rolling guides installed on fast-finishing blocks and on servo-assisted device for rolling rings changing. In fact, this equipment has shown effective benefits on our test plants and has mainly cut out the tendency of the personnel to be absent due to backache. This paper will first present standard working conditions, will then introduce the newest equipment developed by Danieli \& C. Officine Meccaniche Spa, will analyze its operation and finally will describe in detail the benefits that can be reached with its use.
\end{abstract}

Keywords: Roller guides; Wire rod blocks; Danieli; Safety.

1 Engineer, Vice President, Service Long Products Mills, Danieli \& C. Officine Meccaniche Spa, Buttrio, UD, Italy.

2 Sales manager, Guide System, Danieli do Brasil S.A., São Paulo, Brazil.

* Technical contribution to the 51st Rolling Seminar - Processes, Rolled and Coated Products, October $28^{\text {th }}$ to $31^{\text {st }}, 2014$, Foz do Iguaçu, PR, Brazil. 


\section{INTRODUCTION}

Nothing is more important than the safety and health of the people who work in the steel industry [World Steel Board of Directors].

Safety and working conditions are two of the main targets on which steel manufacturers have recently focused their attention.

New steel plants offer now a completely different working environment compared to the past and improvements are continuously being introduced on the market.

The following main factors push companies to improve safety conditions of their employees:

- social responsibility

- laws and regulations

- certifications

- insurance charges

- personnel experience

Safety and health principles guide almost all companies up to the top levels.

The Word Steel Association pushes members to adopt the following six principles [1]:

1. All injuries and work-related illnesses can and must be prevented.

2. Management is responsible and accountable for safety and health performance.

3. Employee engagement and training is essential.

4. Working safely is a condition of employment.

5. Excellence in safety and health supports excellent business results.

6. Safety and health must be integrated into all business management processes.

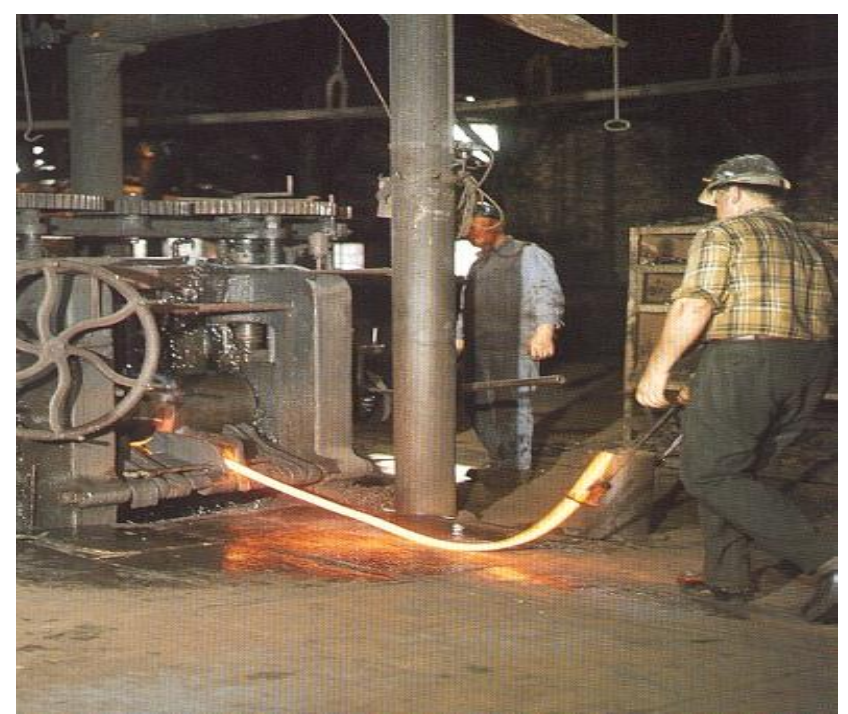

Figure 1. Typical working condition in Europe during the early '60s.

* Technical contribution to the 51st Rolling Seminar - Processes, Rolled and Coated Products, October $28^{\text {th }}$ to $31^{\text {st }}, 2014$, Foz do Iguaçu, PR, Brazil. 

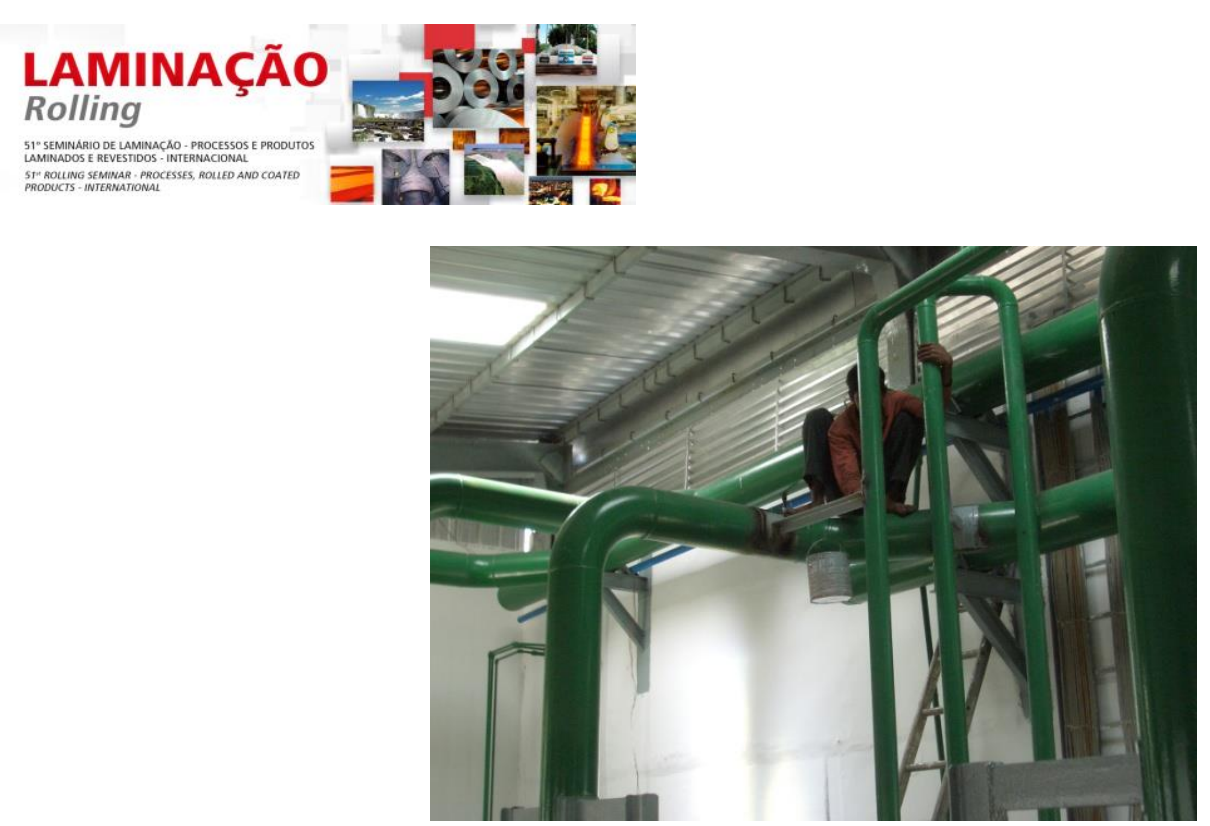

Figure 2. Working conditions which today can be found in some countries.

Therefore the attention of steel companies is not limited to reduce accidents and injuries, but to prevent work-related illnesses as well.

One of the main cause of work-related illnesses is the manual handling of goods that brings about musculoskeletal disorders. For example in Great Britain 439000 cases of musculoskeletal disorders have been reported on 2011/2012, corresponding to $41 \%$ of total cases of self-reported work-related illnesses [2].

There is no universal maximum weight limit allowed for manual handling. In some countries the law foresees maximum 20 or $25 \mathrm{~kg}$; in some others, it assigns duties to employers to manage and control the risk.

Moreover there is no universally safe maximum weight, depending this on many aspects (body structure, type of movement, repetition etc.).

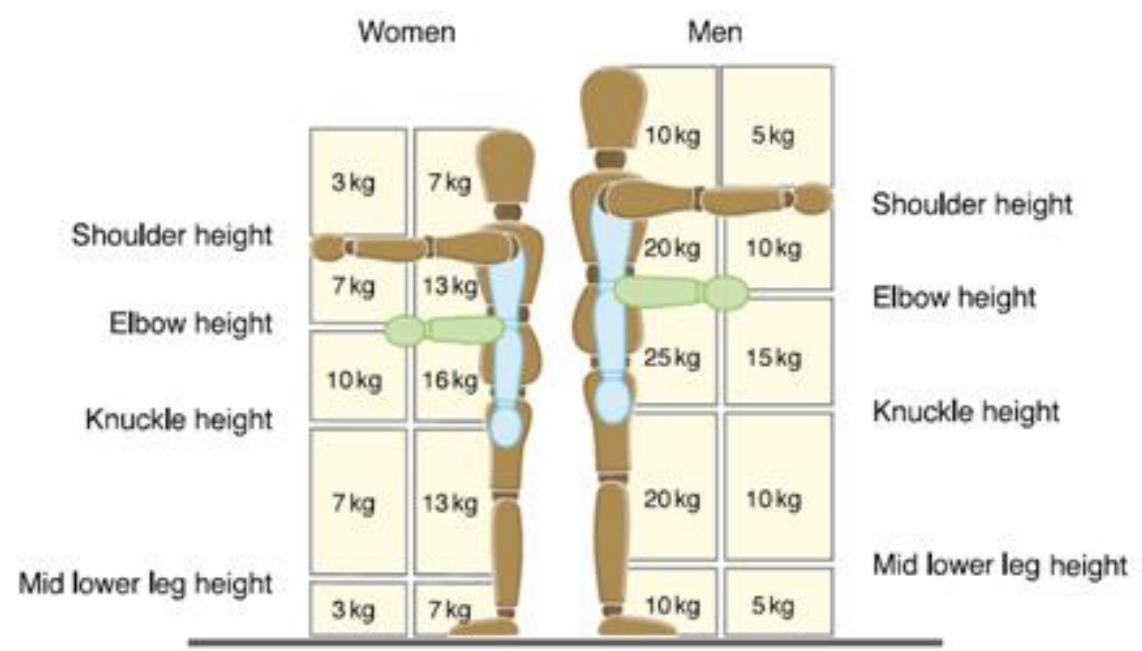

Figure 3. Weight guideline for lifting and lowering [3].

On a steel plant there are many operations that are subject to manual handling.

Danieli \& C. Officine Meccaniche Spa - the leading company for long-product rolling mills - continually develops new solutions improving not only the productivity and the reliability of the equipment installed but also the working conditions of its operators. This is aimed at increasing the level of safety and reducing work-related illnesses.

We will present two examples of improvements applied to two types of equipment which in a rolling mill require frequent maintenance:

1. Guide equipment

2. Finishing block rings

* Technical contribution to the 51st Rolling Seminar - Processes, Rolled and Coated Products, October $28^{\text {th }}$ to $31^{\text {st }}, 2014$, Foz do Iguaçu, PR, Brazil. 


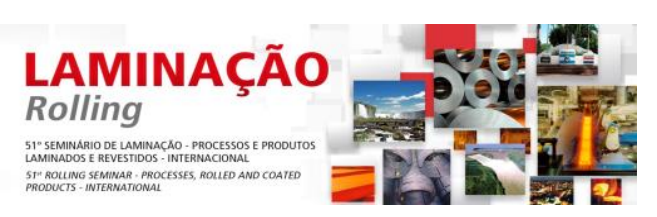

These improvements can greatly simplify the every-day operators' working conditions.

\section{MATERIAL AND METHODS}

\subsection{Guide Equipment}

Guide equipment is one of the key factors increasing the productivity of a rolling mill and the quality of final products. Morgårdshammar invented and patented the first roller guide in 1944 and since then it is the pioneer in guide technology covering all product ranges (bar, wire rod and section) with standard and tailor-made equipment. Different types of guides are used in a rolling mill. Roughing stands use heavy guides, but they are usually moved with the support of cranes or lifting tools. On the contrary, in a finishing mill and wire-rod blocks guides are manually changed on-line thanks to cassette-type mounting, and this operation is performed quite frequently (even twice or three times every day, excluding events like cobbles or operators setting mistakes).

There is no standard practice on guide replacing: what can be done is usually planned for the following reasons:

-product change

-groove change

-guide roller wearing

-guide bearing wearing

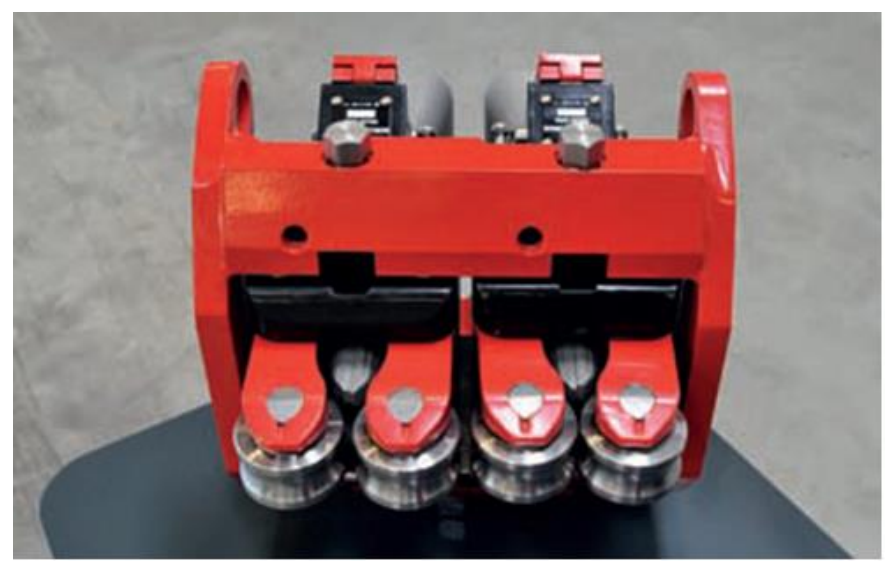

Figure 4: Cassette-type mounting for two strand slitting

Therefore each plant plans guide changing differently, taking into consideration rolling conditions (rolling campaign duration, rolling speed etc.) and material used (steel or carbides, high or low quality bearings etc.). Guide changing is usually performed in the finishing mill and in general only roller guides are critical for replacement. In static guides some consumable parts can be replaced as rule (entry guide halves or exit pipes) but their lifetime is higher and weight is lower compared to roller guides.

Moreover, each guide that needs be replaced on-line has to be manually handled at least 3-4 times by the operators, which means heavy repetitive weight to be moved.

Danieli \& C. Officine Meccaniche Spa concentrates its efforts not only to continuously develop Morgårdshammar roller guides from the technical point of view (the 1100series has been recently launched into the market): beside this, it has newly introduced the possibility to have the same roller guide having a lower weight thanks

* Technical contribution to the 51st Rolling Seminar - Processes, Rolled and Coated Products, October $28^{\text {th }}$ to $31^{\text {st }}$, 2014, Foz do Iguaçu, PR, Brazil. 


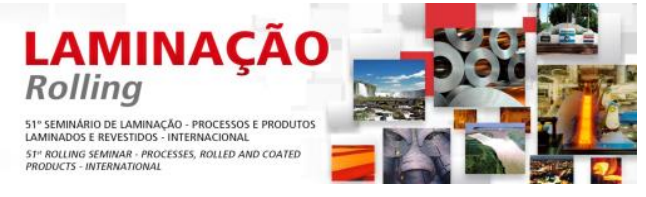

to a guide box made of light alloy (thus without affecting its mechanical properties). The specific weight of this alloy is $2,8 \mathrm{~kg} / \mathrm{dm}^{3}(64 \%$ lighter if compared to standard stainless steel): the use of this material on a guide box (which is the heaviest part of the guide) will lead to spare $25-30 \%$ on guide weight.

Let us consider for example the wire-rod block guide SRW-E.

This guide represents the most innovative roller guide for wire-rod blocks with excellent performances for high-speed or high-quality production.
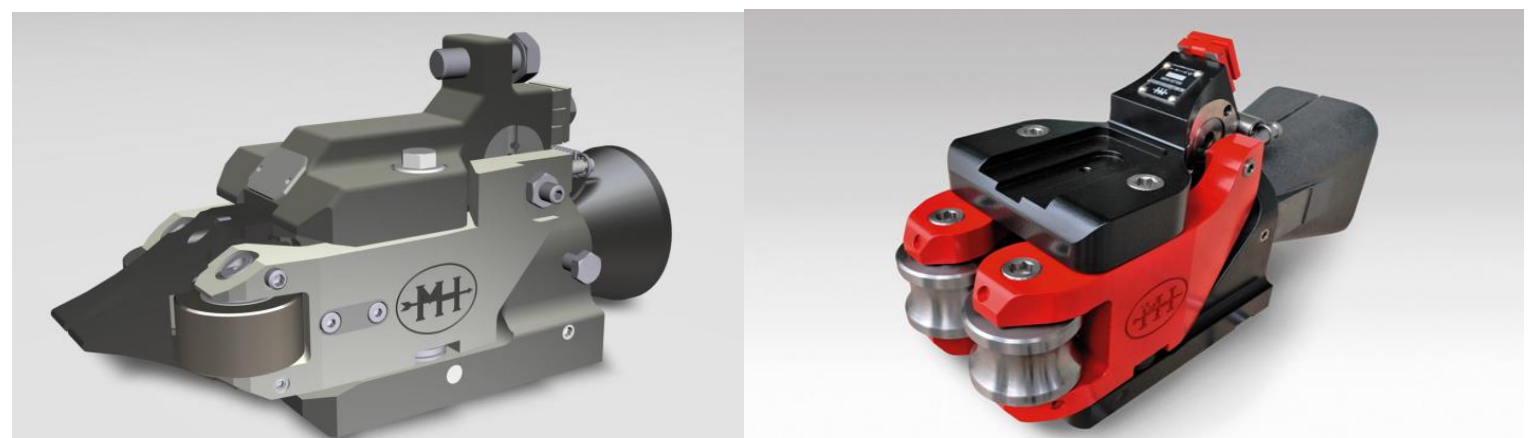

Figure 5: New Morgardshammar SRW-E Entry Roller Guide for Wire Rod Block (left) and SR-E guide for rolling mill (right)

This guide has been developed following the previous 1000-series features:

- Optimized V-shaped base for quick and repetitive precise mounting.

- Simultaneous fine adjustment for rollers by single central screw.

- Individual adjustment for each roller holder.

- Independent vertical adjustment for all rollers.

- Zero-clearance system for top stability, control and guiding precision at high speed.

- No external pipe for media supply to grant quick replacement.

- Longer lifetime of each component to reduce maintenance and operative costs.

- 18, 24, 30 and $40 \mathrm{~mm}$ roller availability (including Ferrodur rollers).

The performances of these guides have been successfully proven in rolling mills at a high speed $(126,6 \mathrm{~m} / \mathrm{s}$ in Ferriere Nord - Italy) and also in rolling mills producing topquality specialty steel (Cogne Acciai Speciali, Nucor Darlington, ...).

The standard version of the SRW-E guide is made of high-quality materials, mainly stainless steel (forged roller holders and casted guide boxes). The weight of this roller guide, equipped with rollers and entry guide halves, is approx $17 \mathrm{~kg}$.

The weight of the "light" version of the same guide, made of a light-alloy guide box, is $12,5 \mathrm{~kg}(-26 \%)$. This guide is much easier to be handled in a delta-type wire-rod block where operators have to work in a not upright position.

Likewise, SR-E guides - in their smaller versions (the ones that are manually handled) - are available with a light-alloy guide box. Such guides have similar features to SRW-E but are used on rolling mills.

By using light guides, in the below-simulation considering a typical 26-pass rolling mill, operators can spare $26,5 \%$ of guide handling weight (for manually moved guides), equal to 42 tons (not always moved in favourable conditions).

* Technical contribution to the 51st Rolling Seminar - Processes, Rolled and Coated Products, October $28^{\text {th }}$ to $31^{\text {st }}, 2014$, Foz do Iguaçu, PR, Brazil. 


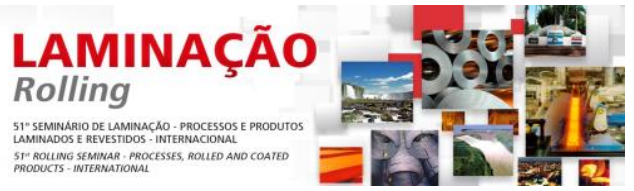

Table 1: simulation of weight manually handled for roller guides.

\begin{tabular}{|c|c|c|c|c|c|c|c|c|c|}
\hline \multicolumn{2}{|c|}{ 列 } & \multicolumn{2}{|c|}{$\begin{array}{l}\text { ROLLER GUIDE WEIGHT } \\
(\mathrm{kg})\end{array}$} & & \multicolumn{2}{|c|}{ MOVED WEIGTH $(\mathrm{kg})$} \\
\hline $\begin{array}{l}\text { STAN } \\
\text { D }\end{array}$ & $\begin{array}{l}\text { ROLLE } \\
\text { R } \\
\text { GUIDE }\end{array}$ & $\begin{array}{l}\text { STANDARD } \\
\text { VERSION }\end{array}$ & $\begin{array}{l}\text { LIGHT } \\
\text { VERSION }\end{array}$ & $\begin{array}{l}\text { REPLACEMEN } \\
\text { T/DAY (nr) }\end{array}$ & $\begin{array}{l}\text { WORKING } \\
\text { DAY (nr) }\end{array}$ & $\begin{array}{l}\text { HANDLING/GUI } \\
\text { DE (nr) }\end{array}$ & $\begin{array}{l}\text { YEARLY } \\
\text { HANDLIN } \\
\text { G (nr) }\end{array}$ & $\begin{array}{l}\text { STANDAR } \\
\text { D } \\
\text { VERSION }\end{array}$ & $\begin{array}{l}\text { LIGHT } \\
\text { VERSIO } \\
\mathrm{N}\end{array}$ \\
\hline 15 & SR20 & 27 & 19,7 & 0,5 & 330 & 3 & 495 & 13365 & 9751 \\
\hline 17 & $\begin{array}{l}\text { SRW- } \\
30 \mathrm{E}\end{array}$ & 17 & 12,5 & 0,5 & 330 & 4 & 660 & 11220 & 8250 \\
\hline 19 & $\begin{array}{l}\text { SRW- } \\
30 E\end{array}$ & 17 & 12,5 & 1 & 330 & 4 & 1320 & 22440 & 16500 \\
\hline 21 & $\begin{array}{l}\text { SRW18- } \\
\text { E }\end{array}$ & 17 & 12,5 & 1 & 330 & 4 & 1320 & 22440 & 16500 \\
\hline 23 & $\begin{array}{l}\text { SRW18- } \\
\text { E }\end{array}$ & 17 & 12,5 & 2 & 330 & 4 & 2640 & 44880 & 33000 \\
\hline 25 & $\begin{array}{l}\text { SRW18- } \\
\mathrm{E}\end{array}$ & 17 & 12,5 & 2 & 330 & 4 & 2640 & 44880 & 33000 \\
\hline & & & & & & & TOTAL & 159225 & 117001 \\
\hline & & & & & & & & $\begin{array}{l}\text { DELTA } \\
(\mathrm{kg})\end{array}$ & 42223 \\
\hline & & & & & & & & $\begin{array}{l}\text { DELTA } \\
(\%)\end{array}$ & $-26,5 \%$ \\
\hline
\end{tabular}

\subsection{Rolling Rings for Wire Rod Block}

Replacing of rolling rings is another repetitive activity that has to be performed in a wire-rod mill. There are different factors influencing the frequency of this activity, such as:

- Production change

- Quality of rings

- Steel grade and quality of final product

A typical sequence of ring change on a 10-pass wire-rod block plans to change rings every 8-12 hours on finishing passes and every 48 hours on entry passes.

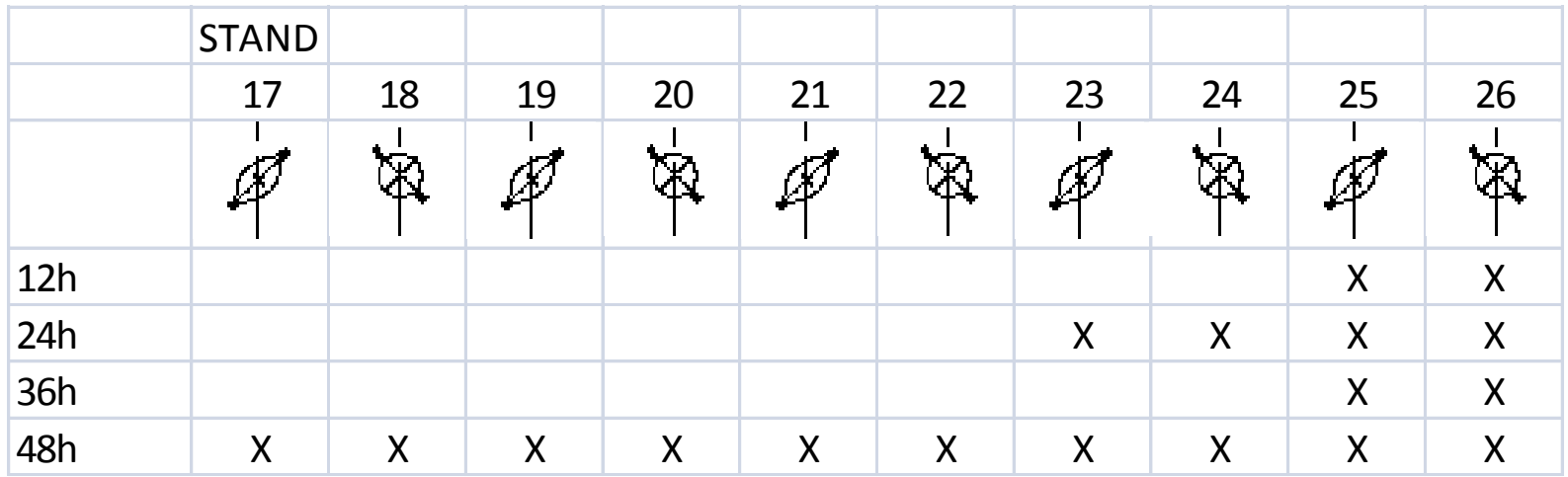

Figure 6: Typical ring changing sequence on a 10 passes WRB.

Backache and fingers' crushing are the main possibility of trauma that operators may encounter by ring changing. This may happen considering also the non-ergonomic working position and the weight of the parts subject to change (approx $20 \mathrm{~kg}$ each ring and $18 \mathrm{~kg}$ the locking unit).

* Technical contribution to the 51st Rolling Seminar - Processes, Rolled and Coated Products, October $28^{\text {th }}$ to $31^{\text {st }}$, 2014, Foz do Iguaçu, PR, Brazil. 


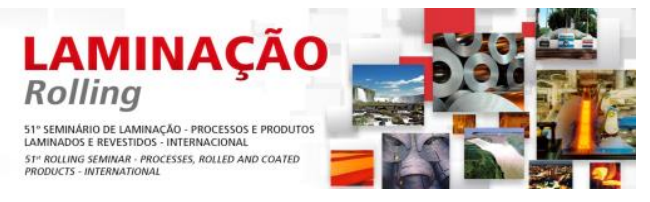

Table 2: Simulation of weight manually handled for rings and locking systems

\begin{tabular}{|l|r|r|r|r|r|r|r|}
\hline & $\begin{array}{l}\text { Rings to } \\
\text { be } \\
\text { changed }\end{array}$ & $\begin{array}{l}\text { Weight } \\
\text { (ring + } \\
\text { locking) }\end{array}$ & $\begin{array}{l}\text { REPLACEMENT/DAY } \\
\text { (nr) }\end{array}$ & $\begin{array}{l}\text { WORKING } \\
\text { DAY (nr) }\end{array}$ & $\begin{array}{l}\text { HANDLING } \\
\text { (nr) }\end{array}$ & $\begin{array}{l}\text { YEARLY } \\
\text { HANDLING } \\
(\mathrm{nr})\end{array}$ & $\begin{array}{l}\text { MOVED } \\
\text { WEIGHT } \\
(\mathrm{kg})\end{array}$ \\
\hline $12 \mathrm{hr}$ & 4 & 38 & 0,5 & 330 & 2 & 330 & 50160 \\
\hline $24 \mathrm{hr}$ & 8 & 38 & 0,5 & 330 & 2 & 330 & 100320 \\
\hline $36 \mathrm{hr}$ & 4 & 38 & 0,5 & 330 & 2 & 330 & 50160 \\
\hline $48 \mathrm{hr}$ & 20 & 38 & 0,5 & 330 & 2 & 330 & 250800 \\
\hline
\end{tabular}

\section{RESULTS AND DISCUSSION}

In a rolling mill there are many operations that imply to manually lift heavy weights in a repetitive way and usually in not comfortable conditions. The above-mentioned examples show two of these operations having as a consequence to manually lift 600 tons. The use of new equipment and tools can reduce the weight that people have to uplift, thus improving not only their working conditions but drastically reducing the consequences of this operation such as injuries and work-related illnesses (in particular backache).

Even though this equipment has been recently developed, there are not many longterm results we can show. Anyway, in the first company where our manipulator has been installed since almost 2 years (in North Italy), its use has completely cancelled the operators' absence due to backache, optimizing at the same time shifts preparation and improving personnel satisfaction.

\section{CONCLUSION}

Changing social responsibility together with new laws and regulations induce companies to improve working and safety conditions almost in every country and business sector including steel industry; this top-down changing demand meets the same urgent requests of mill operators to work in better conditions. Therefore soon or later mill managers will be forced to think about the introduction of new tools and equipment in their rolling mill.

Mill and equipment manufacturers now develop their equipment keeping into consideration all these requests coming from their customers. In some cases mill constructors even anticipate these requests thanks to these new technologies.

\section{REFERENCES}

1 Safety and Health Principles and Definitions. Guidance Book. World Steel Association. 2013

2 Annual statistic report for Great Britain. 2012/2013. The Health and Safety Executive [internet]. 2013 [cited 2014 June 6]; page 8. Available from: http://www.hse.gov.uk/statistics/overall/hssh1213.pdf

3 Manual handling at work. A brief guide. The Health and Safety Executive. [internet]. 2012 [cited 2014 June 6]; page 8. Available from:

http://www.hse.gov.uk/pubns/indg143.pdf

\footnotetext{
* Technical contribution to the 51st Rolling Seminar - Processes, Rolled and Coated Products, October $28^{\text {th }}$ to $31^{\text {st }}$, 2014, Foz do Iguaçu, PR, Brazil.
} 